DOI https://doi.org/10.18551/rjoas.2018-01.12

\title{
THE IMPACT OF COMPENSATION AND JOB MOTIVATION ON EMPLOYEE PERFORMANCE WITH JOB SATISFACTION AS MEDIATING VARIABLE: A STUDY AT BALI REGIONAL OFFICES OF DIRECTORATE GENERAL OF TAXES
}

\author{
Verozika Andry \\ Department of Human Resource Development Program, University of Airlangga, Indonesia \\ E-mail: verozika@gmail.com
}

\begin{abstract}
The purpose of this study is to analyze and obtain empirical evidence related to the compensation and job motivation toward the performance of employees of the Directorate General of Taxes through job satisfaction as mediating variables. The subject of this research is the employee of Bali Regional Office of Directorate General of Taxes. This research is explanatory with the number of respondents as many as 190 people. Methods of data collection through surveys using questionnaires. Data analysis technique used in this research is Regression Analysis and Path Analysis. The findings of this study showed that Compensation and Job Motivation had a significant effect towards Job Satisfaction, Compensation and Job Motivation had a significant effect towards Employee Performance. Furthermore, Job Satisfaction had a significant effect towards Employee Performance.
\end{abstract}

\section{KEY WORDS}

Compensation, motivation, job satisfaction, employee performance.

The Indonesia Directorate General of Taxes (DGT) has an important duty as an institution for collecting state revenues from the taxation sector. In the last decade, Indonesia's national income tax sector increasingly important because over the years, the proportion of state revenues from the tax sector increases. If in 2007 the proportion of tax revenue amounted to $61.6 \%$ of the total national income, in 2017 increased to $80 \%$ of the total national income and reached 1.498 trillion rupiah. Based on these achievements, in 2018 the goals target of national tax revenue set at Rp. 1.618 trillion. To improve the performance of DGT employees, the government provides special compensation system through Presidential Regulation no. 37 of 2015 in order to motivate tax officials in achieving organizational goals. Compensation is one element of human resource management system that can support the creation of organizational performance effectiveness and motivate employees to achieve high performance. Compensation consists of as any form of compensation the employee receives as a result of the completion of duties and performance within the organization, including prizes, rewards and other incentives. Castertter (1996) mentions that one of the purposes of compensation is to motivate employees to show optimal performance, so that employees' perception of compensation whether given fairly or not will affect their next performance. This is in accordance with Payne (2002) which states that compensation is one determinant of employee satisfaction, which will motivate employees to increase their productivity work. If the employee feels that his work will be rewarded with a fair compensation system then the employee will feel satisfied and motivated to produce better performance and vice versa if the employee feels his work is not appreciated then the employee's performance will decrease.

According Mangkunegara (2007) motive is a boost in the needs of employees who need to be met so that employees can adapt to their environment, while motivation is a condition that moves employees to be able to achieve the purpose of motive. Motivation has been a key issue for researchers studying organizational and individual performance for a number of years. It is seen as a major determinant of performance, and is considered a vital element in the relationship between compensation and performance when compensation is seen as a factor that motivates individuals to perform work. Organizational objectives will be achieved if all existing resources can be optimally utilized by the institution. The human 
resources that will be used to manage the resources of an organization must have the high motivation necessary to manage the existing resources so as to provide maximum benefits. This utilization will be very closely related to the performance of each employee of the organization or company.

Robbins, et al (2003) briefly states that the relationship of job satisfaction with employee performance is a statement: "A happy worker is a productive worker" (for individuals). If applied in an organization then it can be said that organizations with satisfied employees tend to be more effective so that its performance is increasing.

\section{LITERATURE REVIEW}

According to Efendi (2012) compensation is the total remuneration received by employees as a result of the implementation of work in the organization in the form of money or other. If the compensation received by the employee can meet the needs of the employee, then the employee will strive to continue achievement that will certainly contribute to performance employees. Previous research has found that compensation has a positive and significant effect on employee performance (Artana, 2012: Sahlan, 2015: Suwati, 2013).

Panggabean (2004: 76) classified compensation into two groups, financial or nonfinancial. There are direct and indirect financial compensation. Direct financial compensation consists of salary / wages and incentives (commissions and bonuses). While indirect financial compensation can be a variety of facilities and benefits. Nonfinancial compensation consists of work environment, such as interesting tasks, exciting new challenges, acknowledgment, sense of accomplishment, working relationships, comfortable working environment etc.

Job satisfaction is the attitude of the individual and the emotional state of an employee to the job, the rewards received and the rewards that are believed to be received either in the form of financial compensation (salary or allowances) or non-financial such as promotional opportunities and psychological environment such as calming partners (Robbins, 2003). According to Luthans (2006) job satisfaction is influenced by several factors, among others: satisfaction with the work itself, ie variations in a particular job, methods and work procedures; satisfaction with compensation ie financial rewards received by employees include salaries and benefits; satisfaction of promotional opportunity, Opportunity to be promoted seems to have a diverse influence on job satisfaction, because the promotion can be in different forms and varied in return; satisfaction with supervision, Supervision is another important source of job satisfaction; satisfaction with groups or colleagues, Basically, the working group will affect the job satisfaction. Friendly and cooperative colleagues are a source of job satisfaction for individual employees; satisfaction with the condition / work environment, If good working conditions for example, then the employee will be more eager to work.

Motivation is a process of stimulating people to carry out activities in an effort to achieve the desired goals or targets effectively and efficiently (Adisasmita, 2011). Herzberg (in Waluyo, 2007) classifies motivation into two factors. The first factor, namely the motivator includes salary, wages, bonuses, corporate policies and administration, job security, working conditions, supervision guidance, and guidance co-workers. The second factor, namely hygiene that includes progress, recognition and status, occupation, achievement, growth possibilities, and responsibility. Perry and Wise (1990) gave three types of motives which encourage people to work. These are rational, norm-based and affective motives. Rational motives are concerned with self-interest, norm-based motives encourage behaviours oriented to the public interest, while affective motives concern willingness to help other people.

Dessler (2011) defines performance as a work achievement that is a comparison between the actual performance of employees compared with the expected performance of employees. According to Simamora (2006), performance is defined as the achievement of certain job requirements that ultimately can be directly assessed based on the resulting output.According to Handoko (2008)there are many factors that affect employee performance. Employees performance depends on motivation, job satisfaction, stress level, 
physical condition of work, compensation system, job design and other economic, technical and other aspects. There are 6 (six) criteria for assessing employee performance according to Bernardin and Russel (1993) : (1) the quality of work, (2) the quantity of work, (3) timeliness, (4) Cost effectiveness, (5) Need for supervision, (6) Interpersonal impact.

\title{
METHODS OF RESEARCH
}

The study used a quantitative research methods, with the variables: compensation, job motivation, job satisfaction and employee performance. This research can be categorized as a causality research. The location of this research at the regional office of the directorate general of taxes of Bali. Sampling technique used in this research is to use Simple Random Sample. Margono (2004) states that simple random sampling is a technique to get a sample directly conducted on the sampling unit. simple random sampling is used because the population is relatively small. The samples was 190 respondents. This study used a questionnaire distributed to respondents. To examine the relationship between these variables, inferential analysis was used in the form of Path Analysis. The research framework is presented in Figure 1.

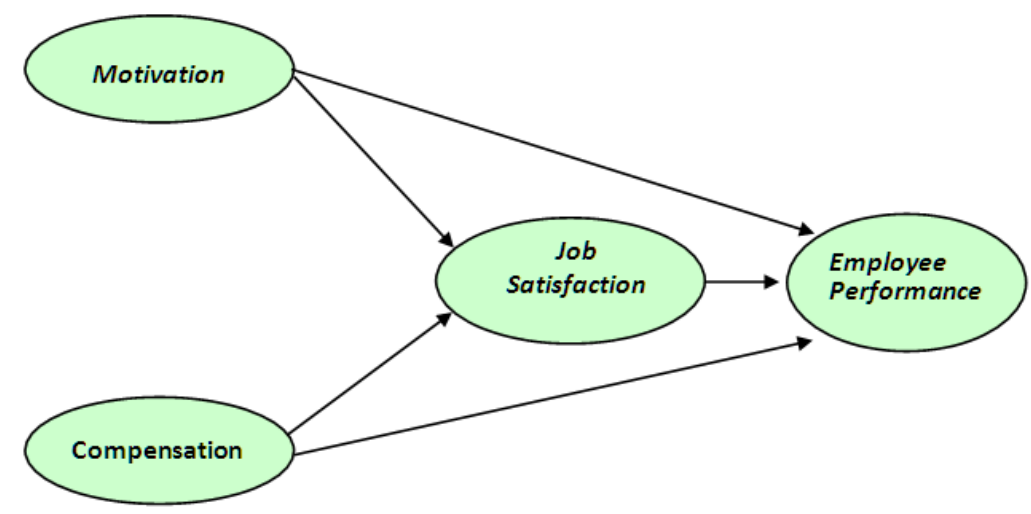

Figure 1 - Research Framework

\begin{abstract}
Hypotheses:
$\mathrm{H} 1$ : Compensation and Job Satisfaction have a significant correlation;

$\mathrm{H}_{2}$ : Compensation and Employee Performance have a significant correlation;

H3: Job Motivation and Job Satisfaction have a significant correlation;

$\mathrm{H} 4$ : Job Motivation and Employee Performance have a significant correlation;

H5: Job Satisfaction and Employee Performance have a significant correlation.
\end{abstract}

\section{RESULTS AND DISCUSSION}

Hypothesis 1 stated that Compensation (X1) has a significant effect on job satisfaction (Y1). The results of regression analysis of Compensation (X1) on Job Satisfaction (Y1) which the results showed a significant probability value ( $p$-value) of 0.000 with the path coefficients (beta) of 0.430 and a significance value less than 0.05 . It can be concluded that the data support the hypothesis $\mathrm{H} 1$ where there is significant influence between Compensation (X1) on Job Satisfaction (Y1). This means compensation have a positive and significant effect on job satisfaction. This result supported by research results from Adeoye and Fields (2014) which concluded that there is a relationship between compensation and employee job satisfaction. This supports the view expressed in the many literature that if workers are dissatisfied with their compensation, the organization will experience low levels of job satisfaction, high absenteeism, and labor rotation. 
Table 1 - Output of Path Analysis

\begin{tabular}{|c|c|c|c|c|}
\hline Model & Path Coefficient & $\mathrm{t}$ & $\mathrm{p}$ & $\mathrm{R} 2$ \\
\hline \multicolumn{5}{|c|}{ Structural Model I } \\
\hline$X_{1}-Y_{1}$ & 0,430 & 7.161 & 0.000 & \multirow{2}{*}{0.502} \\
\hline $\mathrm{X} 1-\mathrm{Y} 2$ & 0,385 & 6.406 & 0.000 & \\
\hline \multicolumn{5}{|c|}{ Structural Model II } \\
\hline $\mathrm{X}_{2}-\mathrm{Y} 1$ & 0,138 & 2.012 & 0.046 & \multirow{3}{*}{0.490} \\
\hline $\mathrm{X}_{2}-\mathrm{Y}_{2}$ & 0,427 & 6.351 & 0.000 & \\
\hline$Y_{1}-Y_{2}$ & 0,244 & 3.297 & 0.001 & \\
\hline
\end{tabular}

Notes: Compensation ( $\left.X_{1}\right)$, Job Motivation ( $\left.X_{2}\right)$, Job Satisfaction (Y1), Employee Performance (Y2).

Hypothesis 2 stated that compensation (X1) significantly influence the employee performance $(Y 2)$ with significant value 0,000 smaller than a (0.05). This means that the higher the compensation given by the company will encourage producing a good and high

employee performance. On the other hand compensation gives significant effect on employee performance with influence value of 0.385 or $38.5 \%$. This means that compensation has a positive and significant effect on employee performance. In line with research from Qureshi and Sajjad (2015) which shows a positive relationship between compensation and employee performance. The effect of compensation on employee performance is also reinforced by Hameed et al. (2014) in his research, as well as research conducted by Jamil and Raja (2011) in which positive and significant compensation practices relate to the performance of public sector organization employees. Compensation is required to encourage employees to work harder in the hope of increasing the benefits they receive. Therefore compensation is the main entity that affects employee performance.

Hypothesis 3 stated that job motivation (X2) significantly influence to job satisfaction (Y1) with significant value 0,001 smaller than $\alpha(0.05)$. This means that the higher the job motivation given by the company will produce both good and higher job satisfaction. Job motivation significantly effects on job satisfaction with the value influence 0,138 . This means motivation have a positive and significant impact on job satisfaction. Employees are internal consumers who must first be satisfied with their work in order to encourage satisfaction. Satisfied employees generally become more productive employees. Employee motivation is an important factor for the company's progress. Ogunnaike (2014) in his research shows the motivation of work, be it intrinsic motivation or extrinsic motivation is important in increasing job satisfaction.

Hypothesis 4 stated that job motivation (X2) significantly influence employee performance $(\mathrm{Y} 2)$ with significant value 0,000 smaller than $\alpha(0.05)$. This means that the higher the job motivation provided by the company will produce good and high employee performance. Job motivation significantly effects on the employee performance with influence value of 0,427 or $42.7 \%$. The results of this study are consistent with the results of research Seniwoliba dan Nchorbono (2013) which shows the motivation has a significant effect on employee performance. The higher the motivation of work will result in the higher performance of employees. An employee will have a good performance, if it has the desire, expectation, needs, goals, objectives, encouragement, and incentives supported by good work ability. So by motivating and improving the work skills of employees it can improve employee performance in order to maintain the company and still exist in the era of intense competition. Employees with high motivation will produce the best performance and productive, otherwise employees with low motivation will be low performance and productivity (Soegoto, 2009). Employee motivation is a form of willingness to strive to achieve organizational goals by paying attention to efforts to satisfy some needs, as well as efforts to improve and shape the knowledge, attitudes, and behavior of employees so that employees voluntarily try to work cooperatively with other employees to improve

Hypothesis 5 stated that job satisfaction (Y1) significantly influence on employee performance (Y2) with significant value 0,001 smaller than $\alpha(0.05)$. This means that the higher the job satisfaction perceived by employee will produce a good and high employee performance. Job satisfaction has a significant effect on the employee performance with 
influence value of 0.343 or $34.4 \%$. In line with the research of Perera et al. (2014) that job satisfaction has a positive effect on employee performance. According to research Aftab and Idrees (2012) there is a positive relationship between job satisfaction and employee performance. The high performance of each individual will help the organization to achieve strategic goals so as to maintain the competitiveness of the organization. Reinforced by research results from Cloud and Asghar (2014) that employee performance is best when they are satisfied with various aspects of their pay package. Research from Afshar and Doosti (2016) shows job satisfaction positively affect performance. Employee satisfaction tends to make better performance. The factors that contribute most to job dissatisfaction and affect employee performance are low salaries, job demands, low employment status, and social rewards.

\section{CONCLUSION}

The conclusion of this research is there is a significant effect of compensation on employee job satisfaction of Bali regional office of DGT. It can be concluded that the high or low levels of compensation will have an impact on job satisfaction. The higher compensation would encourage better employee satisfaction, while the low compensation would reduce employee job satisfaction. There is a significant effect of compensation on employee performance of Bali regional office of DGT. This means that better compensation given will be directly in proportional to the increasing of the employee performance. There is a significant influence of job motivation on employee job satisfaction of Bali regional office of DGT. It can be concluded that the better job motivation for employees will increase employee job satisfaction and vice versa, the decrease in employee job motivation practices will reduce employee job satisfaction. There is a significant influence of job motivation on employee performance. It can be concluded that the growing of the job motivation also supports employee performance improvement. It was found that there was a significant effect of job satisfaction on the performance of employees of Bali regional office of DGT. It can be concluded that good job satisfaction of the employees would be able to improve employee performance and conversely, the decline in employee job satisfaction helped reduce employee performance. It was found that in job motivation variables, indicators of training, promotion program and assessment program had been in line with expectations of respondents. It was also found that indicators that have the highest percentage score is satisfaction for colleagues. while the indicator with the lowest value is satisfaction of promotion opportunity. Job satisfaction factors still need improvement in the pattern and basis of consideration for promotion or mutation of employees. The current promotional system is not considered fair and transparent enough. Rotation and Promotion of employees also need to be re-evaluated to fit the existing compensation system. It has been found that in the variable employee performance, the indicator that has the highest percentage score is Quantity of Work while the indicator with the lowest value is work effectiveness.

\section{REFERENCES}

1. Adeoye, A.O., Fields, Z. 2014. Compensation Management and Employee Job Satisfaction: A Case of Nigeria. Journal Social Science, Vol. 41, No. 3, pp. 345-352.

2. Artana, I, Wayan, Arta, 2012, Pengaruh Kepemimpinan, Kompensasi, dan Lingkungan Kerja terhadap Kinerja Karyawan (Studi Kasus di Maya Ubud Resort \& Spa), Jurnal Perhotelan dan Pariwisata Vol, 2, No. 1, Hal. 66, Agustus 2012

3. Adisasmita, Rahardjo. 2011. Manajemen Pemerintah Daerah. Yogyakarta: Graha Ilmu.

4. Afshar, H. S. dan Doosti, M. 2016. Investigating the Impact of Job Satisfaction/ Dissatisfaction on Iranian English Teachers' Job Performance. Iranian Journal of Language Teaching Research, Vol. 4, No. 1, pp. 97-115.

5. Bernardin. 1993. Human resources Management, New York: Prentice Hall. Boulte 
6. Casetter, W.B, 1996. "The Human Resource Function in Educational Administration, 6th ed". New Jersey. Prantice-Hall.

7. Dessler, Gary. 2010. Manajemen Sumber Daya Manusia, Jilid I. Prehallindo. Jakarta.

8. Efendi, Sofian dan Tukiran. 2012. Metode Penelitian Survey. Jakarta : LP3ES

9. Funmilola, 2013. "Impact of Job Satisfaction Dimensions on Job Performance in a Small and Medium Enterprise in Ibadan, South Western, Nigeria". Interdisciplinary Journal Of Contemporary Research In Business. Vol. 4. No.11. pp. 509-521.

10. Handoko, T. Hani, 2008. Manajemen Personalia Sumber Daya Manusia, Edisi. Kedua, Yogyakarta

11. Jamil, B., 2011. "Impact of Compensation, Performance Evaluation and Promotion Practices on Government Employees Performance VS Private Employees Performance". Interdisc. Journal of Contemporary Research in Business, Vol. 3, No. 8, December 2011, 907-913.

12. Luthans, Fred. 2006. Perilaku Organisasi, Alih Bahasa: V.A Yuwono, Edisi Bahasa Indonesia. Penerbit Andi. Yogyakarta.

13. Mangkunegara, Anwar Prabu, 2007, Manajemen Sumber Daya Manusia, Cetakan Ke Tujuh PT. Remaja Rosdakarya, Bandung

14. Margono (2004) Metodologi Penelitian Pendidikan. Jakarta

15. Panggabean, S., 2004. Manajemen Sumber Daya Manusia. Bogor: Ghalia Indonesia.

16. Perera, G.D.N., Khatibi, A., Navaratna, N., dan Chinna, K. 2014. Job Satisfaction and Job Performance Among Factory Employees in Apparel Sector. Asian Journal of Management Sciences \& Education, Vol. 3, No. 1, pp. 96-104.

17. Payne, Adrian, 2002. Manajemen Sumber Daya Manusia, Penerbit Andi Offset, Yogyakarta

18. Perry, James L., and Lois Recascino Wise. 1990. The Motivational Bases of Public Service. Public Administration Review 50(3): 367-373

19. Qureshi, M.O. dan Sajjad, S.R. 2015. An Empirical Analysis of the Impact of Compensation on Job Performance and Work-Family Conflict in the Kingdom of Saudi Arabia a Correlation Model. European Scientific Journal February 2015 edition, vol.11, No. 4, pp. 170-187.Rivai, Veithzal, Ella Jauvani Sagala. 2010. Manajemen Sumber Daya Manusia untuk Perusahaan dari Teori ke Praktik, Edisi 2. Rajawali Pers. Jakarta.

20. Rivai, Veithzal. 2008. Manajemen Sumber Daya Manusia untuk Perusahaan dari Teori ke Praktik. Raja Grafindo Persada. Jakarta.

21. Robbins, Stephen P. 2003. Perilaku Organisasi, Konsep, Kontroversi, Aplikasi, Alih Bahasa: Hadyana Pujaatmaka. Prehallindo. Jakarta.

22. Seniwoliba, A.J dan Nchorbono A.D. 2013. "Examining the Role of Motivation on Employee Performance in the Public Sector in Ghana". Merit Research Journal of Education and Review (ISSN: 2350-2282) Vol. 1(10) pp. 227-249, November, 2013.

23. Simamora, Henry. 2006. Manajemen Sumber Daya Manusia, Edisi 2, STIE YKPN.

24. Sugiyono. 2008. Metode Penelitian Bisnis. Alfabeta. Bandung.

25. Waluyo, 2007, Perpajakan Indonesia, Buku 1 Edisi 7, Penerbit Salemba Empat, Jakarta. 